\title{
The Trendelenburg Test: Simple Method to Avoid Wound Healing Complications after Cranioplasty
}

\author{
Jamie A Spitz ${ }^{1 *}$ and Marco F Ellis ${ }^{2,3,4}$ \\ ${ }^{1}$ Department of Plastic Surgery, The Ohio State University, Columbus, USA \\ ${ }^{2}$ Division of Plastic, Reconstructive, and Cosmetic Surgery, University of Illinois, Hospital and Health Science System, USA \\ ${ }^{3}$ Division of Plastic and Reconstructive Surgery, Northwestern University Feinberg School of Medicine, USA
}

${ }^{4}$ Department of Neurological Surgery, Northwestern University Feinberg School of Medicine, USA

Submission: April 08,2019; Published: June 07, 2019

*Corresponding author: Jamie Spitz, Department of Plastic Surgery, 915 Olentangy River Rd, Suite 2100 Columbus, USA

\section{Abstract}

Background and Importance: The syndrome of the trephined is a disorder of transient neurological deterioration that may be present in patients with a large calvarial defect. There is often prompt reversal of the symptoms following cranioplasty. Assessing the skin deficit in trephined patients can be challenging.

Clinical Presentation: We present a patient who required cranioplasty for a large calvarial defect and describe a simple, efficient method to assess the skin and soft tissue deficit for preoperative evaluation.

Conclusion: The technique presented herein is a safe and efficacious method of addressing the skin deficit in trephined patients. We have been using this strategy routinely and believe that other surgeons may also benefit from it.

Keywords: Cranioplasty; Preoperative evaluation; Scalp reconstruction

\section{Introduction}

The syndrome of the trephined is a disorder of transient neurological deterioration that can occur in patients with a large calvarial defect. The symptoms range from seizures, headache, neuropsychiatric disturbance, focal weakness, midbrain syndromes, and Parkinsonian symptoms [1]. Following cranioplasty there is increased cerebral metabolism, CSF pressure normalization, and improvement in cerebral hemodynamics, which lead to reversal of the neurological symptoms [1]. Nakamura first noted prompt reversal of speech worsening and right hemiparesis after moving the patient to a horizontal or Trendelenburg position, along with restoration of the curvature of the scalp flap [2].

Therefore, cranioplasty reconstruction is of the utmost importance in patients with the syndrome of the trephined. Postcraniectomy defects, related to intracranial bleeding or infection, often require composite reconstruction of the calvarium, skin and soft tissues [3]. During preoperative examination, it is often difficult to determine if there is an accompanying skin defect. The scalp is sunken and may not easily re-expand to the pre-existing contour and surface area to accommodate a cranioplasty implant.
Currently there is no standard for determining whether the trephined patient will benefit from collaborative plastic surgery involvement. Herein we present a simple method of evaluating patients with large post-craniectomy defects preoperatively to aide in planning the reconstruction.

\section{Clinical Presentation}

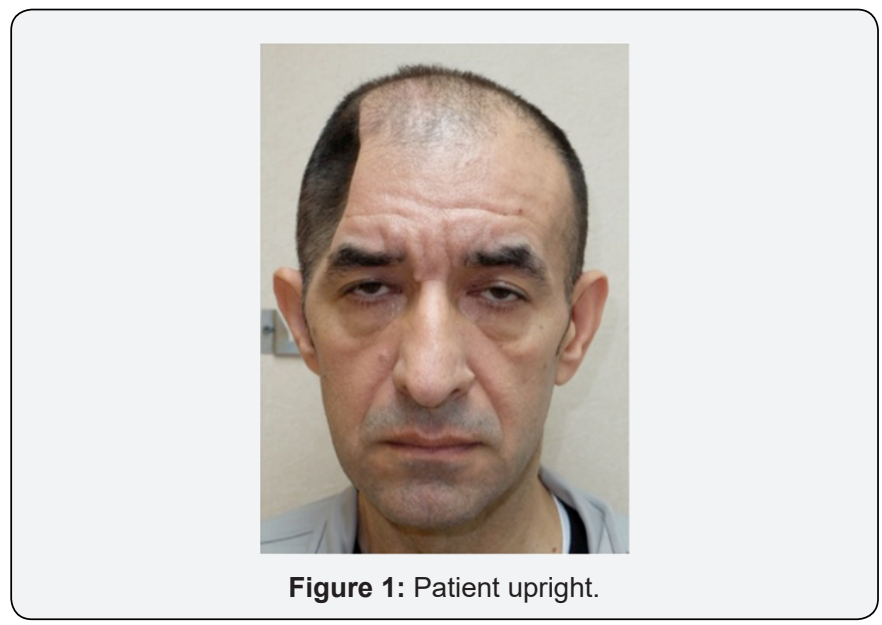


In the preoperative evaluation, we place the patient in a flat supine position on the exam table to measure the scalp elasticity and ability for the brain to re-expand. The patient first sits upright which clearly delineates the calvarial defect (Figure 1). Next the patient is brought into a flat supine position (Figure 2) to demonstrate the distensibility of the scalp skin and soft tissue from the increased intracranial pressure. The amount of expansion obtained with the position change can be used to approximate how much expansion will be gained after recreating the defect in the operating room.

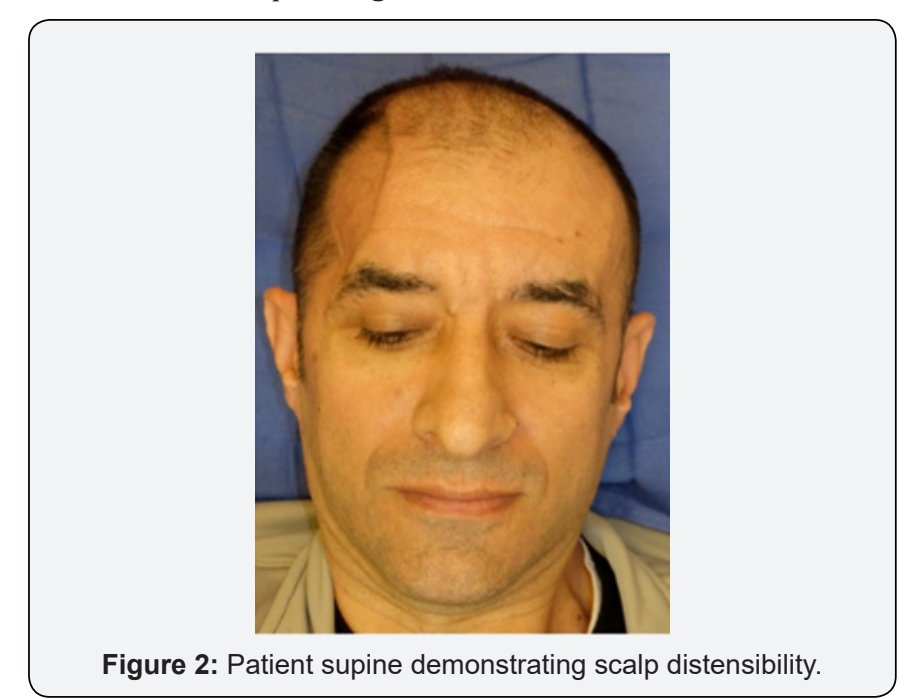

\section{Discussion}

This knowledge can be used preoperatively to guide reconstruction planning and patient expectations. Patients are simply kept in a flat supine position. We prefer the eponym Trendelenburg to reference how this positional change can momentarily improve neurocognition in addition to help with preoperative planning. In our experience, patients that fail this test are those whose scalp remains tight and convex, which can represent inelastic soft tissues or adherent dura and brain with little capacity to restore intracranial volume. Our recommendation for the former is the use of a vascularized flap, whether free tissue or locally based, to offset tension on the final scalp closure. Cases with adherent dura require staged reconstruction with free tissue transfer and delayed cranioplasty $[3,4]$.

\section{Conclusion}

We believe that the technique presented herein is a safe and efficacious method of addressing the skin deficit in trephined patients. It is quick to perform and requires no specialized equipment. We have been using this strategy routinely and believe that other surgeons may also benefit from it.

\section{References}

1. Sedney CL, Dillen W, Julien T (2015) Clinical spectrum and radiographic features of the syndrome of the trephined. J Neurosci Rural Pract 6(3): 438-441.

2. Nakamura T, Takashima T, Isobe K, Yamaura A (1980) Rapid neurological alteration associated with concave deformity of the skin flap in a craniectomized patient. Case report. Neurologia medico-chirurgica 20(1): 89-93.

3. Mundinger GS, Latham K, Friedrich J, Louie O, Said H, et al. (2016) Management of the Repeatedly Failed Cranioplasty Following Large Postdecompressive Craniectomy: Establishing the Efficacy of Staged Free Latissimus Dorsi Transfer/Tissue Expansion/Custom Polyetheretherketone Implant Reconstruction. J Craniofac Surg 27(8): 1971-1977.

4. Kumar AR, Tantawi D, Armonda R, Valerio I (2012) Advanced cranial reconstruction using intracranial free flaps and cranial bone grafts: an algorithmic approach developed from the modern battlefield. Plast Reconstr Surg 130(5): 1101-1109.

\section{Your next submission with Juniper Publishers will reach you the below assets}

- Quality Editorial service

- Swift Peer Review

- Reprints availability

- E-prints Service

- Manuscript Podcast for convenient understanding

- Global attainment for your research

- Manuscript accessibility in different formats

( Pdf, E-pub, Full Text, Audio)

- Unceasing customer service

Track the below URL for one-step submission

https://juniperpublishers.com/online-submission.php 